\title{
A homiletic reflection on the theological aesthetics involved in picturing God in a fragmented South African society
}

\author{
Authors: \\ Ben J. de Klerk ${ }^{1}$ \\ Friedrich W. de Wet ${ }^{1}$ \\ Rantoa S. Letšosa ${ }^{1}$ \\ Affiliations: \\ ${ }^{1}$ Department of Practical \\ Theology, North-West \\ University, South Africa \\ Note: \\ This article is published in the \\ Section Practical Theology \\ of the Society for Practical \\ Theology in South Africa.

\section{Correspondence to:} \\ Friedrich de Wet \\ Email: \\ fritz.dewet@nwu.ac.za

\section{Postal address:} \\ Faculty of Theology, PO Box \\ 20004, Noordbrug 2522, \\ South Africa \\ Dates: \\ Received: 12 Jan. 2011 \\ Accepted: 04 May 2011 \\ Published: 14 Oct. 2011 \\ How to cite this article: \\ De Klerk, B.J., De Wet, \\ F.W. \& Letšosa, R.S., 2011, \\ 'A homiletic reflection on \\ the theological aesthetics \\ involved in picturing God in \\ a fragmented South African \\ society', HTS Teologiese \\ Studies/Theological Studies \\ 67(2), Art. \#1018, 8 pages. \\ http://dx.doi.org/10.4102/ \\ hts.v67i2.1018
}

(C) 2011. The Authors. Licensee: AOSIS OpenJournals. This work is licensed under the Creative Commons Attribution License.
This article investigates the problematic field of authentic speech in a fragile South African society where the imminence of shattering fragmentation is often addressed either by aggravating hate- speech or pacifying speech that seems to lack the will to come to terms with the full implications of the issues at hand. We attempt to reflect on the possibility of authentic speech in this context by picturing God and his purposeful presence in our fragmented world; speech that reflects and acts out the implications of what is observed in the revealing light of God's living Word. In addressing the research problem the following aspects are researched: (1) we briefly reflect on the theological aesthetics involved in picturing God through the eyes and acts of faith, (2) explore the painful manifestation of fragmentation in the South African society (with poverty and HIV and AIDS as examples), and (3) attempt to homiletically speak the language of faith by picturing God in our fragmented world through the lens of the parable of the Good Samaritan. We come to the conclusion that authentic homiletic speech can only flow from a heart in which the hardened crust of perpetual attempts at self-righteousness and conservation of the own comfort-zone are shattered by the words and deeds of our Lord. It is through the words and deeds of our Lord that the preacher is enlightened to bear authentic witness to how God fuses a shattered reality and a shattered heart into a prismatic, multifaceted witness to the glory of his all-conquering healing power.

\section{To picture God in a fragmented society}

As we write this research report we find ourselves in a South African society filled with concern regarding instances of crime and mounting racial tension; a society not exactly resembling a rainbow nation, but displaying the features of a place of vulnerability finding itself yet again on the verge of shattering into fragments of irreconcilability and isolation. Prevailing instances of violent crime and accompanying victimisation in the South-African society cause some researchers to draw the conclusion that the situation borders on a form of anarchy that threatens the peaceful lifestyle of established citizens (Kruger \& Ladikos 2008:439; Strydom \& Schutte 2005:115). In a report analysing the South African government`s development indicators for 2010 (presented to the media on 14 December 2010 by Trevor Manuel) several troubling patterns seem to surface. The report indicates that less than half of South Africans $(46 \%)$ hold the opinion that race relations improved during the past year. The percentage of people who share this opinion have not been this low since May 2003, when 48\% citizens held this view. The report mourns the fact that almost a quarter of adult citizens of the country have in some or other form been victims of crime (Steenkamp 2010:1).

Over the Easter weekend (04 April 2010) a far right wing political leader, Eugène Terre`Blanche, was brutally murdered on his farm. This act prompted rhetoric from a wide spectrum:

- Political parties condemn the act and in some cases draw a connection between the murder and the leader of the ANC youth league, Julius Malema's actions in repeatedly singing a liberation song during public gatherings containing the words Dubul ibhunu [shoot the farmer] ${ }^{1}$.

- Other people have interpreted this as an isolated incident that amounts to no reason for national alarm. President Jacob Zuma responded with a general call to stay calm and very discreetly asked leaders to take the responsibility upon them not to make statements that may be interpreted wrongly by others ${ }^{2}$.

After the politicians with their rhetoric, ranging from agitation, to self-justification and attempts at pacification have spoken, the preacher needs to picture the presence of God in this fragmented, tension-filled society and speak words that reflect the impact of this presence. This brings to mind the often-quoted words of Brueggemann in his publication, Finally comes the poet (1989:7): 'Then

1.The singing of this song seems to be rooted in the actions of liberation movements prior to 1994 , which had inter alia, been characterised by attacks on farms by Azanian People's Liberation Army (APLA) members and land-mine explosions caused by members characterised by attacks on farms by Azanian Peop)
of Umkhonto we Sizwe (MK) (Moolman 2000:64).

2.A mere symbolic reference to the political struggle of the past, might for instance be misinterpreted by others as referring to the current political situation. 
perchance comes the power of poetry - shattering, evocative speech that breaks fixed conclusions and presses us always toward new, dangerous, imaginative possibilities.'

In this research report we reflect on the speech, which proceeds from a heart shattered by the image God reveals about his purposeful presence in our fragmented world. This speech is broken open by the aesthetic vision of faith that, through painful perception of the reality of brokenness, leads to acts embracing God's unimaginable grace in restoring the seemingly 'unrestorable':

- we reflect on the theological aesthetics involved in picturing God through the eyes and acts of faith

- we explore the painful manifestation of fragmentation in the South African society

- we attempt to homiletically speak the language of faith by picturing God in our fragmented world through the lens of the parable of the Good Samaritan.

\section{Picturing God through the eyes and acts of faith}

When speaking about picturing God, the question regarding the subjectivity involved in this action field immediately surfaces. To what extent is the action of picturing God a product of anthropocentric reflection, imagination and construction? Or are the eyes opened to see and to act upon a revealed picture that entails much more than we could ever have imagined? At its core the problematic field involved in this question has to do with elements like subjectivity, correspondence, reciprocity and sovereignty and/or dependence in the divine-human relationship. Barth categorically said 'no' to the human pretension implicit in natural theology and cultural Christianity and gave his unequivocal 'yes' to the triumph of grace as the only way of redemption. The doctrine of the 'analogy of being' analogia entis (a theological concept that goes back to a particular interpretation of Paul's assertion that God's invisible qualities, his 'eternal power and divine nature', are discernable in creation itself [Rm 1:20]) according to Barth led Catholic theology into errors that amounted to the manipulation of God rather than obedience to God as a sovereign subject. Whether it was the anthropological turn in liberal theology that made human beings the subject, or the ecclesiastical control of God's grace through the Catholic sacramental system, God's freedom and grace were compromised (De Gruchy 2001:115-116).

When reflecting on the issue of picturing God from a theological position that finds its roots in the Calvinistic tradition, the key words seem to be revelation and faith:

- God reveals himself and his purpose with this world in the form of a comprehensive history of salvation as it is described in Spirit inspired Scripture. This revelation (described in Scripture) portrays God as the one that relates himself in an all- encompassing way to this world as its Creator, Redeemer and Consummator. The Scripture (Sola Scriptura) contains everything we need to know regarding the origin, meaning, purpose and destination of life.

- The revelation of God is perceived through faith. The act of picturing God can only take place through the eyes of faith (Sola Fidei) and can only lead to acts of faith in glorifying God (Soli Deo Gloria).

In the concept of faith the origin of perception, imagination and action does not lie in natural human ability, but in the grace of God that opens blind eyes to see and cures hardened hearts to willingly pursue his revealed purpose to the glory of his name. Through the lens of Scripture a clear vision of God's purposeful presence in the reality we find ourselves in, is opened up. Although God 'accommodates' (a term frequently used by Calvin [cf. Runia 1981:83]) himself to our finite minds and limited thought patterns in order to communicate the message of eternal salvation in Scripture, unregenerated humanity is not inclined to take in what is plainly visible or plainly pictured and is not able to reflect on the hidden riches that lie beneath the surface. This can be illustrated by means of different reactions to the parables of the kingdom frequently employed by Jesus Christ. For some, the parables are revealing, for others they are concealing. The kingdom, although present, is hidden and perceived only by the eyes of faith. Those who harden their hearts (Is 6:10; Mk 4:12) are not helped by the parables of the kingdom. To the contrary they are confirmed in their blindness and the Gospel becomes a word of judgement to them. To those who respond in faith; however, God reveals the glorious truth of his 'plan for the fullness of time' (Eph 1:10; cf. Rottenberg 1980:16). The kingdom of God is present as the transforming power of God's future; it is manifested in our midst through the power of the Holy Spirit. The fact that this is God's power is not self-evident. In this sense the kingdom does not come 'with observation' (Lk 17:20). However, those who have eyes to see will indeed see (Rottenberg 1980:19).

When reflecting on the impact that divine revelation has on the human being that receives and embraces it through faith, the perception-forming instruments of clinical rational deduction do not suffice. Modernity's deity is in the principled, cold, impassive, rational and mechanical, whereas a genuinely Trinitarian theology expresses the beauty, love, wonder and surprising creativity of God (De Gruchy 2001:115). The unimaginable and surprising brightness of the light of God's grace that is revealed when the curtains of our own closed and limited thought-patterns are drawn aside, call for the integration of the aesthetic dimension. Without the aesthetic dimension reflection can potentially be reduced to a 'ganz amusisches Gedankenleben' (Bohren 1975:16).

Balthasar laments the loss of aesthetics in the modern culture and particularly in theology. He is convinced that the beautiful is the language of light, the vehicle of God's revelation. Once we have lost the language of light, once humanity has forgotten that the mystery of being and its ultimate meaning is revealed to us through the beautiful 
and not primarily through rational deduction, we can no longer discern in being the Gestalt of God's beauty of which all creation speaks (Zimmermann 2004:309). In the opinion of Cilliers (2010:1), religious aesthetics could be understood within the dynamic interplay between beauty, goodness and truth. Where these dimensions of God's revelation coincide, an aesthetical event is constituted. And vice versa, where this interaction is compromised, aesthetics as such is shattered (German: verkitschen) and in effect, 'superficialised'. Beauty becomes sentimentality, truth generalisations and goodness moral domestication.

Theological aesthetics, in our view, offers a much needed meta-theoretical base for engaging the subtleties in the complex relationship between divine disclosure and faith perception, and for faithfully (not superficially) getting to grips with the unimaginable richness (the vast dimensions of the boundary-shattering length and breadth and depth of God's love in Christ) entrusted to us in the revelation of God as it is intended be embodied in the reality we find ourselves in. For the purpose of our research project we depart from the aesthetical category of perception (German: Blick) with the intent to indicate how renewal of perception can lead to renewal of praxis. According to Grözinger, an aestheticaltheological reflection on Blick undoubtedly has immediate relevance for Practical Theology:

Wenn es der Blick ist, über den sich unvermeidlich die Weltwahrnehmung konstituiert, dann ist jedes Handeln wiederum durch diesen Blick bestimmt, weil jedes Handeln aus ein bestimmten Welt-Sicht lebt und auf die Bewahrung oder Revision einer solchen Welt-Sich aus ist. Nur wer blickt, kann auch handeln. Und jedes Handeln setzt seinerseits aus sich einen neuen Blick heraus. Damit wird der Blick zu einem zentralen Problem auch der Praktischen Theologie.

(Grözinger 1987:243)

Van Erp (2004:44) reasons that theological aesthetics points to a faithful receptivity to beauty (and ugliness) without ignoring the creative and often difficult work of constructing images of faith. According to Cilliers (2009:35) aesthetic reasoning could be brought to fruition within the framework of practical theology as follows: the latter is about the praxis of God's presence amongst us (often called God's beauty), revealed in certain embodied encounters. Practical theology studies the ways in which people try to make sense out of these embodied encounters, therefore it hinges on an existential hermeneutics.

When describing the contribution of theological aesthetics as faithful receptivity towards God's revelation in Scripture with the resulting construction of images of faith that flows from this receptivity and that reflects the praxis of God's presence amongst us, a clear definition of the hermeneutical process involved is necessary. When departing from a pneumatological model in attempting to describe the hermeneutics involved, Scripture is not viewed as mere text leading to insight, but opens up a living relationship with the heart of God's revelation in the Logos, Jesus Christ. Receptivity under guidance of the Spirit entails being renewed with the mind of Christ and calls for embodiment according to his image:

- seeing the glory of God and the fullness of his will from the perspective of the One that was with his Father from all eternity

- looking at reality and interpreting what we see in this world through his eyes

- lamenting the absence of the embodiment of his reconciling love in the spheres of life that we find ourselves in

- engaging in acts that seek to embody God`s healing presence in this world.

In Zimmermann's (2004) view theological hermeneutics wants to recover the premodern notion that:

There is only one reality and that is the God-reality in the reality of the world which was revealed through Christ. Participating in Christ we are at the same time in God-reality and in worldreality. The reality of Christ contains the reality of the world. The world does not possess a reality independent from God's revelation in Christ.

(Zimmermann 2004:307)

Receptivity and construction of faith images are then not to be thought of apart from unity with Christ through the working of the Spirit.

The essence of the connection between what is received through revelation (culminating in faith union with Christ) and the construction of faith images (with the eye on getting to grips with what we have been shown and relating it to God`s presence in our world) should also be considered. Bohren (1976) expresses the relationship between receptivity and construction via the double sense implicated by the concept of Wahrnehmung:

Darum versuche ich, Praktische Theologie als theologische Ästhetik zu verstehen. Gottes Handeln, Gottes PraktischWerden, will wahrgenommen werden in diesem doppelten Sinn. Von einem wahrnehmenden Erkennen und von einem Wahrnehmen des Auftrags.

(Bohren 1976:316)

The aesthetic implications of what is shown to us and observed by us are so far-reaching that it cannot but lead to the observation that new deeds in this world are in need of God's grace and destined to reflect the glory of God without hindrance. Looking at a broken world through the eyes of Christ (that was filled with so much compassion for what he saw that he laid down his life for this world) fills the aesthetic vision with unclouded pain and inevitably leads to acts of faith that freely minister God's healing love to the world. The act of picturing God in a fragmented world therefor does not merely entail constructing a picture in the sense of representation, but ultimately expresses itself in a call for action. Perception does not end in (melancholic) contemplation, but leads to social-ethical action. Without incarnation as archetypically beautiful, this sense of unreachable majesty so necessary to the experience of the sublimely beautiful leads to melancholy since we can never attain it (Zimmermann 2004:314). 


\section{Exploring the painful manifestation of fragmentation in South African society}

The brief exploration of instances of fragmentation in the South African society (documented in this section of the research report) is done with a focus on describing the homiletic event of theological-aesthetically looking at reality through the lens of Scripture. This theologicalaesthetic observation culminates in speaking and acting the language that needs to be become active in these particular circumstances.

What is fragmentation? The word stems from the Latin word fragmentum, which can convey the sense of breaking or separating (something) into fragments (American Heritage Dictionary 2009). Fragmentation can then, in a negative sense, refer to the act of dividing the integral parts of a given object up till the point of disintegrating and shattering its underlying unity. In a sociological context fragmentation then refers to the absence or the underdevelopment of cohesive relationships between members of a particular society as well as the disintegration of these relationships due to the way differences in factors like race, ethnicity, gender, sexual orientation, socio-economic status, age, physical abilities, religious beliefs and political beliefs are managed. Forces like isolation, discrimination and estrangement come into play.

The concept of fragmentation may however also be interpreted positively: in a positive sense fragmentation can refer to diversity with the element of underlying unity remaining intact. The concept of diversity encompasses acceptance, respect and acknowledgement of the fact that the other perspective can enrich the own perspective. In this sense fragmentation is about understanding each other and moving beyond simple tolerance to embracing and celebrating the rich dimensions of diversity contained within each individual as a member of an integral group. Diversity within the underlying unity portrays a multicoloured beauty in the creation of God (Wilson 1998:36).

From a theological perspective the world we live in, is perceived through the eyes of faith as God's world. In the reformed worldview, God is pictured as the one who created the world. He is the one who still reigns in every sphere of the universe. This world is seen as anchored in the creative, redemptive and consummative work of the Triune God. Living in this world, man as image of God is supposed to reflect the glory of God. As a result of sin and disobedience, not only did relationships between God and fellow humans become distorted, but also the world we live in, became a fragmented (broken) world. The aim of God's children, having been reconciled to God through Christ, will be to minister this reconciliation in the world they live in (2 Cor $5: 18,19)$. In the process of ministering reconciliation, they will picture the multi-coloured grace of God as a manifestation of his goodness, love, righteousness and holiness in a unified world full of diversity, like a prismatic light which shines upon and shapes our world into a multifaceted diamond exploding with living light and flaming colour to the glory of God.

Two examples of fragmentation in the South-African context (as defined in the above sense of reflecting a shattered reality and calling out for ministry of reconciliation) will now be discussed; namely the manifestation of poverty and HIV and Aids.

\section{Poverty}

Whatever financial system, economical model, political order or welfare scheme has been deployed in the course of history, poverty seems to prevail as a problematic issue that will always remain with us. In trying to understand the prevailing reality of poverty, the rhetoric of hope has frequently been utilised, even if it only amounts to a desperate tactic in creating the illusion of hope for those caught in the vicious cycle of hopelessness. The preacher, in forming a homiletic perspective, painfully becomes aware that rhetoric in the context of poverty frequently promises a better future, but that these words almost always prove to be empty and in vain (Du Toit 1997:285). Poverty concerns society in its totality. It poses a threat to everyone. The following scenario (as it progressively unfolds) is a typical example that illustrates the inability of false hope to break the vicious cycle and farreaching effects of poverty:

- poor people from rural areas constantly migrate to urban areas in hope of job opportunities

- in cities the prospect of work frequently does not materialise

- poverty-related conditions still prevail and deepen

- without money some people even begin to turn to crimerelated activities in order just to stay alive.

A working definition of poverty is essential in order to determine who the poor are and where they are situated. The World Bank defines poverty as 'the inability to attain a minimal standard of living' (Woolard \& Leibbrandt 2001:42). Those who cannot afford basic amenities such as food, clothing and shelter are considered poor. Williams (1998) in turn says:

... poverty is never simple. It is a complex amalgam of physical
and spiritual pain, which robs the person and the community
of dignity and meaning as much as it deprives the body of
nourishment, shelter and beauty. Poverty is about exclusion and
power, about lack of choice and limitation of freedom. But all of
these are related to lack of money.

(Williams 1998:3)

Dimensions of poverty include powerlessness, vulnerability, bodily weakness, financial insolvency (material poverty), social isolation and even spiritual deprivation (see Brandt 1995:260). What it must truly feel like to be subjected to all these dimensions of poverty is virtually unimaginable.

What does poverty look like on global scale? The 31 poorest nations worldwide - with the exception of six - are found on the African continent. On a global scale it is estimated that 
someone dies of starvation every 3.6 seconds. Three-quarters of these deaths concern children under the age of five (Mitchell 2000:252). At least $75 \%$ of the world's population shares $25 \%$ of the world's wealth. This fundamental economic inequality has left the majority of the world's population in dire need of resources.

Poverty is endemic in Africa where an estimated half of the population lives on less than $\$ 1.00$ per day. An estimated $75 \%$ of Africa's inhabitants live on less than $\$ 2.00$ a day (Binns \& Robinson 2002:26). In South Africa, the combination of poverty together with HIV and Aids is a contributing factor to a very low life expectancy: the estimated life expectancy as indicated in 2008 is 48.5 years for men and 52.7 years for women. Furthermore, the infant mortality rate is estimated to be 56 per 1000 live births. The hungry suffer from insufficient health care, lack of sufficient assets, shortages of training and skills. They spend the major part of their income $(70 \%-80 \%)$ on food, mostly inexpensive starchy staple foods (Du Toit 1997:292). To truly observe the reality of brokenness that lies behind these facts and figures is a very painful and disturbing experience. The convenience to merely quote facts and figure and analyse them and leave it at that from a safe distance is not an option for someone who wishes to speak and act the language of the kingdom of God authentically in this unbearable situation.

\section{HIV and Aids}

The Joint United Nations Programme on HIV and Aids (UNAIDS) released a report in 2009 that paints best-case, middle-case, and worst-case scenarios for Africa's AIDS epidemic depending on the international community's commitment to fight the disease. In this report, written by hundreds of the world's leading HIV and AIDS experts in collaboration with people that have actually contracted the disease, all scenarios warn that the worst part of the epidemic is still to come. If more is not done soon, more than 80 million Africans could die by 2025 and 90 million people, more than $10 \%$ of the continent's population, could become HIVinfected. At the time of the report compilation, dying parents in Africa had already left behind 11 million orphans. Some 6500 people are dying of the disease each day, according to UNAIDS.

According to these UN figures, about one in five South Africans are living with HIV and AIDS, the highest caseload of any nation. If the pandemic's risk levels remain the same, by 2015, AIDS will have caused the death of nearly twothirds of all boys who are currently 15 years old in South Africa and Zimbabwe. Even if the risk of transmission were halved, $47 \%$ of 15 -year-old boys in South Africa and $52 \%$ of the same age group in Zimbabwe would have died by then. These statistics are virtually the same for girls who are now 15 years old. The report states:

If steps are not taken immediately to limit the transmission of AIDS to about zero, it might be too late to prevent a catastrophic death toll among the present generation of young men and women.

(UNAIDS in Africa 2009)
The disease is to a certain extent viewed as a private issue and there is still a widespread shame and stigma associated with HIV and AIDS. Because of the fear flowing from possible stigmatisation and rejection, most HIV-positive persons will not even inform their closest relatives, family members or friends of their HIV status. The greatest problem is the stigma and rejection that accompanies HIV and AIDS (UNAIDS in Africa 2009:1). Stigmatisation on a large scale seems to be the order of the day amongst all population groups, because the HIV and AIDS condition is seen as a manifestation of a highly infectious disease that can easily be transmitted in more than one way. In the light of these circumstances HIV and AIDS may be called the leprosy of the modern age. The phenomenon of stigmatisation causes enormous and humiliating pain and loneliness, even for those people who do not involve themselves in acts of promiscuity, like women and men infected by their unfaithful partners within a monogamous marriage, children born with the virus and persons infected through blood transfusions.

Looking at these two manifestations of fragmentation (lives being shattered by poverty and HIV and AIDS and people being estranged from their fellow human beings) through the eyes of Christ fills the vision (of the religious observer) with unbearable pain. This reality does not call for rhetoric that merely creates a safe distance between the speaker and what is seen.

Manifestation of poverty as well as HIV and Aids are two examples of the fragmentation that has far-reaching implication for the socio-political climate in South Africa. These manifestations of fragmentation, amongst others, create a fragile environment; an environment vulnerable to disintegrating forces like corruption, violence and alienation. These manifestations can instigate division in a society where true reconciliation is desperately needed. The question is: how can authentic speech be spoken in this situation? Speech that does not give false hope, speech that does not merely touch the surface and remain unbroken in its alignment towards a shattered reality. Homiletic speech remains impotent, without reconciliatory power and action unless an answer can be found to the question: (How) can God be pictured in this reality?

\section{Homiletically speaking the language of faith by picturing God in a fragmented world through the lens of the parable of the Good Samaritan}

The manifestation of fragmentation in the South-African society, however distressing the facts and figures may seem, can still be ignored and sidestepped by people who find themselves in this dangerous landscape. The preservation of the one's own life and pre-occupation with one's own security can create the illusion of being here and not having to be here at the same time. 
The middle and higher income group can be here in the sense that they care for their own safety and well being, whilst thinking that they do not have to be here in the sense that their lives and destiny are intertwined with that of the poor and stigmatised. In this instance, instead of causing pain and indignation, fragmentation creates isolation and alienation. The privileged are indeed aware of the great need, but are careful not to jeopardise their own position and status in life. The motto is: 'everyone for himself, God for all of us'. The implication of this motto is that God is there for everyone and if you cannot make it in life, you only have yourself to blame and no one else.

The preacher, who has to picture God in this fragmented world, needs to speak a language that shatters illusions and makes people see their lives and inter-connectedness with other human beings in ways they could never have imagined possible. In the process seeing the preacher can help people see God's presence in the most surprising places.

Aesthetically looking through the lens of the parable of the Good Samaritan as Jesus teaches it and by means of which he invites us to into a faith union with him, we see our world through his eyes. Our eyes are focused to see life from the holy angle he employs. What we see from this angle speaks of an abundance of life in a context in which we may have thought that the powers of death and destruction reigned absolute. Bearing in mind that we depart from the aesthetical category of perception (Blick) in the sense of how observation (Wahrnehmung) can lead to renewal of praxis, we now reflect on the parable of the Good Samaritan in its perceptionrenewing implications for homiletic language and the acts that flow from this language.

\section{The parable of the Good Samaritan}

Looking through this lens entails sharpening the focus according to the structure of the parable and vantage point with which it aligns our vision. It entails focusing on the parable and its context as it is deployed in the Biblical text of the Gospel of Luke (10:25-37). In our discussion we explore (1) this passage`s immediate context, (2) the very real connection made to life in this world in the way Jesus deploys the scene and characters, and (3) the teaching that surfaces from this parable.

\section{The context}

Should one proceed from the viewpoint that the so-called wise lacked true understanding (10:21); Luke gave an illustration of just such a lack of understanding. One of the wise, an expert in the law, came to Jesus to ask the most basic of all religious questions, 'what must I do to inherit eternal life?' This question and the parable that follows from it form a unified whole. This is evident as the questions introducing and concluding the parable ( $29 \& 36)$ refer back to the commandment (27) (Stein 2001:314). It is notable that in Luke`s account of bringing the commandment into view, the commandment concerning love for God (Dt 6:5) is not made first whilst the commandment concerning love for the neighbour ( $\operatorname{Lv}$ 19:18) is made second. A single, unified command merges, so that 'love for the neighbour' has the same force as 'love for God' (Johnson 1991:174). A loving relationship with God is manifested in a loving relationship with the neighbour in the concrete praxis we find ourselves in.

The expert in the law's second question: 'and who is my neighbour?' (Lk 10:29), reveals the meta-level on which the issue of keeping the Commandments is sharply focused. The issue at hand is not merely the lack of understanding regarding the correct answer to what it entails to inherit eternal life. At the meta-level the true issue at stake seems to be the attempt to self-righteously contain the implications of the command to a sphere that suits the own uncompromised position (Blight 2007:479). In self-righteousness the circle of neighbours can be reduced to a select few that serve their own purposes. For the scribes the word 'neighbour' was confined only to their fellow Jews. For instance, some of them said that it was illegal to help a gentile woman in her sorest time, the time of childbirth, for that would only have been to bring another gentile into the world. So then the scribe's question, 'who is my neighbour?' as Barclay (2000:138) argues, seemed to be genuine and earnest on the surface but the true motive of self-righteousness could not be hidden from Jesus.

\section{The scene}

The parable is clearly intended to provoke. It is not a sentimental tale that can be sidestepped. It is rooted firmly in the unbearable reality of this broken world in which we have to live with the consequence of our own attitudes and behaviour (Johnson 1991:175). Spence-Jones (2004:275) describes the road from Jerusalem to Jericho as having been a notoriously dangerous road. It was a road of narrow, rocky defiles with sudden turnings, which made it the happy hunting ground of brigands. Jerome mentioned that in the 5 th century it was still called 'The Red, or Bloody Way'. Jesus had these types of incidents in mind when he told this story. Both the priest and Levite were probably frequent travellers along this road between the capital and Jericho. Jericho was especially a city of priests and when the allotted service or residence time at the temple was over, they would return naturally to their own homes. It has been remarked that the grave censure which this story levels at the everyday want of charity on the part of priests and Levites, fills up what would otherwise have been a blank in the Master's many-sided teaching. Spence-Jones (ibid) further argues that nowhere else in the gospel narrative do we find our Lord taking up the attitude of censor of the priestly and Levitical orders. We have little difficulty in discovering reasons for this apparently strange reticence. They were still the official guardians and ministers of his Father's house.

\section{The characters}

There was a traveller. In modern terms, when one investigates the problem of the traveller`s responsibility regarding his own security, one could argue that this man had himself 
to blame. To the modern mind it would seem that he was a reckless and foolhardy character. People seldom attempted the Jerusalem to Jericho road alone when they were carrying goods or valuables. Seeking safety in numbers, they travelled in convoys or caravans.

There was a priest. He hastened past. No doubt he was remembering that he who touched a dead man was unclean for seven days (Nm 19:11). He could not be sure but he feared that the man was dead; to touch him would mean losing his turn of duty in the Temple; and he refused to risk that. He set the claims of ceremonial above those of charity. The Temple and its liturgy meant more to him than the pain of one man (Keener 1993; Blight 2007:482).

There was a Levite. He seems to have gone nearer to the man before he passed on. He could have been well aware of tactic frequently employed by bandits along this dangerous stretch of road. One of their number would act the part of a wounded man; and when some unsuspecting traveller stopped next to him, the others would rush upon him and overpower him. The Levite was a man whose motto was, 'safety first.' He would take no risks to help anyone else. The Levite's conduct was better and worse than his official superior's, better in that he did feel a little pity, and stopped to look, no doubt compassionately, on the sufferer; and worse, because he selfishly strangled the noble impulse in its birth, and passed on to his own place without so much as throwing a cloth over the poor maimed body to shelter it from the scorching sun, or the cold night dew (Spence-Jones 2004:275).

There was the Samaritan. The listeners would obviously expect that with his arrival the villain had arrived. For the sake of strong contrast, Jesus paints on his canvas the figure of one who, as a Samaritan, was as far removed as possible from being a neighbour to the sufferer (who, most probably, was a Jew) in the sense in which the austere Jewish lawyer would himself understand the term 'neighbour.' So great was Jewish and Samaritan hostility that Jesus' opponents could think of nothing worse to say of him than, 'Aren't we right in saying that you are a Samaritan and demon-possessed?' (Jn 8:48; cf. 4:9; Stein 2001:317; Goulden 1994:488). The Samaritan, being a subject of hatred for the Jews, and most probably, in common with the rest of his nation, in a position where he is supposed to hate them, in his turn, was journeying along the ill-omened 'Way of Blood'; he too sees, like the priest, the form of the man, wounded, perhaps to dying, lying by the way and like the Levite, draws near to look on the helpless sufferer. But, unlike the priest and the Levite, stays by the wounded man, and, regardless of peril, trouble, or expense, does his best to help the helpless (Spence-Jones 2004:275; Goulden 1994:488).

\section{The teaching}

Jesus, in his teaching, does not merely clarify a point in the law, but transmutes law into gospel (Johnson 1991:175). Jesus replies to the general question: 'what must I do to inherit eternal life?' with a commendation regarding the correctness of the expert of the law's answer and the exhortation to do this and live (Lk 10:28). His reply to the question that harbours an attempt at self-justification, 'And who is my neighbour?' however amounts to a word of power that is aimed at shattering fixed conclusions and limited adaptability in thinking. His sharply defined question: 'Which of these three do you think was a neighbour to the man who fell into the hands of the robbers?' (Lk 10:36), closes the door for all potential attempts that the listener to the parable could have made to interpret the story to their own advantage and to remain in a passive position. In Jesus` question the focus shifts from the preoccupied notions regarding the issue of who my neighbour is, to the dangerous, unexplored outgoing activity implied in becoming a neighbour for a fallen person in need. The unselfish act of the Samaritan in caring for the wounded traveller and in the process conquering all the fear, isolation, hatred, irreconcilability imbedded in this shattered situation, mirrors the activity of the graceful God that revealed his loving compassion to us in Christ, even while we were his enemies and not worthy of his grace. In the image of the act of the Good Samaritan, a picture of our graceful God materialises, full of the heavenly light of truth and grace.

\section{The implication for homiletically speaking the language of faith in a fragmented world desperately in need of picturing God's presence in its midst}

Looking through the lens of the parable in faith union with Jesus Christ at our fragmented world, our vision is liberation from pre-occupation with our own safety and comfort issues. The inconvenient truth regarding the desperate situation that our fellow South-Africans find themselves in, comes sharply into focus; breaking into our consciousness with sharp pain. We picture God's surprising presence where we least expected it. We see him as the one that is not too hasty to pass by; not too preoccupied to reach out to a human being whose situation seems to be irreparable and making graceful connections with a stigmatised person, however painful it may be to become involved. The stigmas and complications attached to the wounded state of this world is not something that makes him pass by. We see his image clearly in the presence of the one who came to serve and not be served; in the presence of the one who does not ask: 'who can be my servants?', but 'for whom can I be a God; an Immanuel, a neighbour?'

That what is seen through the eyes of faith leads to language that proceeds from a shattered and liberated heart; a heart in which the hardened crust of perpetual attempts at selfrighteousness and conservation of the own comfort zone are shattered by the words and deeds of our Lord. Language is found proceeding from a heart that finds its homiletic expression in glorifying God for his goodness, for showing in a very real sense that no power in heaven or on earth can divide us from his love for us. Language is found in the heart that cannot but morph into homiletic acts of reflecting God's overflowing goodness in wanting with the whole being to be neighbours for the vulnerable, powerless and stigmatised members of our society. 
Looking through the eyes of faith, another picture from the future merges with the frame of the present; an eschatological picture that entails God's divine plan for reconciling this world with him. This plan, which God will complete when the time is right, is to unite everything in heaven and on earth, under Christ as the head (Eph 1:9, 10). In the fullness of time, God's two creations, his whole universe and his whole church, will be unified under the cosmic Christ who is the supreme head of both (Stott 1994:44). In the process of speaking and acting the language of faith, the speaker keeps the eye on the one that moves the glory of his envisaged future into the frame of our present, when he says: 'look, I will make all things new'. The speaker keeps the eye on the appointed Head that will bring all fragments of this broken world together and fuse it into a prismatic, multifaceted witness to the glory of his all conquering healing power.

\section{The significance of the work}

The work attempts to contribute to the question regarding authentic speech in a fragmented South-African society polarised by aggravating hate-speech or disillusioned by pacifying speech that seems to lack the will to come to terms with the full implications of the issues at hand.

\section{Acknowledgements Competing interests}

The authors declare that they have no financial or personal relationship(s) which may have inappropriately influenced them in writing this article.

\section{Authors' contributions}

F.W.D.W. wrote the following sections, 'To picture God in a fragmented society' and 'Picturing God through the eyes and acts of faith'. B.J.D.K. wrote the section 'Exploring the painful manifestation of fragmentation in the SouthAfrican society', whilst R.S.L. was responsible for the section 'Homiletically speaking the language of faith by picturing God in a fragmented world through the lens of the parable of the Good Samaritan'.

\section{References}

American heritage dictionary of the English Language, 4th edn., copyright. 2000 Updated in 2009, Houghton Miffen Company, n.p.

Barclay, W., 2000c, 1975, The Gospel of Luke, The Daily Study Bible Series, rev. edn., The Westminster Press, Philadelphia, PA.
Binns, T. \& Robinson, R., 2002, 'Sustaining democracy in the "new" South Africa', Geography 87(1), 25-37.

Blight, R.L., 2007, An exegetical summary of Luke 1-11, SIL International, Dallas, TX.

Bohren, R., 1975, Daß Gott schön werde: Praktische Theologie als theologische Ästhetik, Kaiser, München.

Bohren, R., 1976, 'Das Wort Gottes und die Kirche', Evangelische Theologie 36(4), 312-324.

Brandt, D.P., 1995, 'The poor and the lost: A holistic view of poverty', Missiology 23(3), 259-266.

Brueggemann, W., 1989, Finally comes the poet: Daring speech for proclamation, Fortress, Minneapolis, MN.

Cilliers, J.H., 2009, 'The beauty of imagened meaning: Profiling practical theological aesthetics', Practical Theology in South Africa 24(1), 32-47.

Cilliers, J.H., 2010, 'The unveiling of life: Liturgy and the lure of kitsch', Hervormde Teologiese Studies 66(2), Art. \#815, 5 pages. http://dx.doi.org/10.4102/hts. v66i2.815.

De Gruchy, J.W., 2001, Christianity, art and transformation: Theological aesthetics in the struggle for justice, Cambridge University Press, Cambridge.

Du Toit, C.W., 1997, 'Empowerment of the poor. Changing our minds on affluence and poverty', Missionalia 25(3), 285-307.

Goulden, M.D., 1994, Luke: A new paradigm, Journal for the study of the New Testament, supplement series 20, Sheffield Academic Press, Sheffield.

Grözinger, A., 1987, Praktische Theologie und Ästhetik: Ein Beitrag zur Grundlegung der Praktischen Theologie, Kaiser, München.

Johnson, L.T., 1991, The Gospel of Luke, Sacra Pagina, vol. 3, The Liturgical Press, Collegeville, PA.

Keener, C. S., 1993, The IVP Bible Background Commentary: New Testament, InterVarsity Press, Downers Grove, IL.

Kruger, F. \& Lakidos, A., 2008, 'Die ontwikkeling van 'n misdaadvoorkomingsmodel binne' $n$ kommersiële produksiegebied', Tydskrif vir Geesteswetenskappe 48(4), 439-453.

Mitchell, N.D., 2000, 'The amen corner: The rest is commentary', Worship 74(3), 248-256.

Moolman, N., 2000, 'Farm attacks: Are there any ulterior motives?', Acta Criminologica 13(2), 64-74

Rottenberg, I.C., 1980, The promise and the presence: Towards a theology of the kingdom of God, Eerdmans, Grand Rapids, MI.

Runia, K., 1983, The sermon under attack (The Moore College Lectures), Paternoster, Exeter.

Spence-Jones, H.D.M., 2004, The Pulpit Commentary: St. Luke, Logos Research Systems, Bellingham

Steenkamp, L., 2010, 'Onmin tussen rasse ál erger', Beeld, 15 Desember, bl. 1.

Stein, R.H., 2001, c1992, Luke (electronic edition), Broadman \& Holman Publishers, Nashville, TN.

Stott, J.R.W., 1994, The Message of Ephesians: The Bible speaks today, InterVarsity Press, Leicester.

Strydom, H. \& Schutte, S.C., 2005, 'A theoretical perspective on farm attacks in the South African farming community', Acta Criminologia 18(1), 115-125.

UNAIDS, 2009, 'Report on the global AIDS Pandemic', UNAIDS, Geneva.

Van Erp, S., 2004, The art of theology: Hans Urs Von Balthasar's theological aesthetics and the foundations of faith, Peeters, Leuven.

Von Balthasar, H.U., 1961, Herrlichkeit: Eine theologische Ästhetik 1, Schau der Gestalt, Johannes, Einsiedeln.

Williams, D.T., 1998, Capitalism, Socialism, Christianity and poverty, Van Schaik, Pretoria.

Wilson, J.R., 1998, Living faithfully in a fragmented world: Lessons for the Church from Macintyre's After Virtue (Christian mission and modern culture), Trinity Press International, Harrisburg.

Woolard, I. \& Leibbrandt, M., 2001, 'Measuring poverty in South Africa', in H. Bhorat, M. Leibbrandt, M. Maziya, S. Van der Berg \& I. Woolard (eds.), Fighting poverty: Labour markets and inequality in South Africa, pp. 41-73, UCT Press, Cape Town.

Zimmermann, J., 2004, Recovering theological hermeneutics: An incarnationalTrinitarian theory of interpretation, Baker Academic, Grand Rapids, MI. 